\title{
THE ACOUISITION OF SOME DIMENSIONAL ADJECTIVES BY BOTH NORMAL AND LANGUAGE-IMPAIRED CHILDREN
}

\author{
SUSAN GAIL WRIGHT, B.A. (SP. \& H. THERAPY) (WITWATERSRAND) \\ Psychological and Guidance Services, Transvaal Education Department, Johannesburg \\ North-West, Johannesburg.
}

\section{SUMMARY}

The main aim of this study was to assess various predictions made by $\mathrm{H}$. and $\mathrm{E}$. Clark with respect to the acquisition of certain dimensional adjectives. In addition, the performance of children with impaired language skills was compared with that of children with normally developing language. Eighteen subjects in the age range 3,3 to 4 years were divided into two groups; those with adequate language ( $\mathrm{C}$ group) and those with impaired language (E group). The dimensional adjective pairs of "length", "tallness" and "width" were investigated on comprehension tasks of increasing dimensionality. A qualitative analysis of the data, for both $\mathrm{C}$ and $\mathrm{E}$ groups, revealed findings supporting the predictions concerning the order of dimensional adjective acquisition in terms of semantic complexity, the acquisition of the unmarked pair member before the marked member, and the acquisition of the concept of polarity before dimensionality. A quantitative analysis of the data revealed significant differences between the $C$ and $E$ groups on a few tasks only. Implications for the researcher and speech therapist are considered.

\section{OPSOMMING}

Die hoofdoel van hierdie studie was om die verskillende voorspellings van $\mathrm{H}$. Clark en E. Clark, met betrekking tot die verwering van sekere dimensionele byvoeglike naamwoorde, te ondersoek. Daarbenewens is die prestasie van kinders met ontoereikende taalvermoëns vergelyk met dié van kinders met normaalontwikkelende taal. Agtien proefpersone, vanaf 3,3 tot 4 jaar, was verdeel in twee groepe; dié met voldoende taal (groep C) en dié met ontoereikende taal (groep E). Die pare dimensionele byvoeglike naamwoorde van "lengte" en "breedte" is ondersoek m.v. begripstoetse van toenemende dimensionaliteit. 'n Kwalitatiewe analise van die gegewens vir albei groepe, het voorspellings aangaande die verwerings volgorde van dimensionele byvoeglike naamwoorde, gebaseer op semantiese ingewikkeldheid, ondersteun - naamlik, die verwerwirig van die ongemerkte deel van die paar voor die gemerkte lid en van die begrip van polariteit vóór dimensionaliteit. 'n Kwantitatiewe analise van die gegewens het betekenisvolle verskille tussen groep C en E op slegs 'n paar take aangedui. Die implikasies vir die navorser en spraakterapeut is bespreek.

The relationship between cognition and language has long been a topic of discussion and presents a controversial area of study. The importance of a conceptual basis for language development is particularly evident when reviewing recent literature concerning the early acquisition of language. ${ }^{4}$ Within this field, attempts have been made to investigate the nature of the acquisition of dimensional adjectives. 2,13 As before, results have revealed varying degrees of disagreement and an integrated overview of this subdivision has yet to be achieved. The present study was undertaken with a view to researching various proposals put forward by the existing theories.

Die Suid-Afrikaanse Tydskrif vir Kommunikasieafwykings, Vol. 28, 1981 
"Most of language is composed of relational terms"11 of which dimensional adjectives form a sub-set. H. Clark, $7,8,9$ in researching the progression and nature of the acquisition of spatial and temporal expressions, has provided a theoretical framework which is widely discussed in the literature. ${ }^{12,17} \mathrm{His}$ hypotheses generally appear to be considered noteworthy and comprehensive, although perhaps not fully explanatory.

H. Clark" bases the evidence for this thesis on the "strong correspondence between the properties of spatial terms and the properties of man's innate perceptual apparatus". He postulates the existence of a perceptual space, or P-space, and a linguistic space, or L-space; thus supporting the notion of a connection between cognition and language. The properties of L-space are predicted to be identical to those of P-space; thus forming his correlation hypothesis. ${ }^{9}$ Biological and physical environments place constraints on the way in which objects may be described in space. ${ }^{9}$ These constraints are determined by P-space properties, which make varying demands on man's perceptions. An area which is easily perceptible may be considered a "positive" perceptual direction as opposed to a "negative" one. Similarly, linguistic forms may differ in complexity; the more complex term is "marked" with respect to the less complex term. The "positive" or "unmarked" term may be comprehended more easily than the "negative" or "marked" term. ${ }^{9}$ The complexity hypothesis is inherent in this proposal.

Dimensional adjectives are divided into adjective pairs defining the dimensions of size, length, distance, tallness, height, depth, width, breadth, and thickness. ${ }^{8}$ These pairs comprise big-small, long-short, far-near, tall-short, high-low, deep-shallow, wide-narrow, broadnarrow, and thick-thin. In terms of the "markedness" theory," the first member of each pair is "unmarked" and the second "marked". This theory is further supported by E. Clark ${ }^{5,6}$ in her advancement of the Semantic Feature Hypothesis (SFH). SFH predicts that the child does not randomly decide which of the two meanings to attribute to the antonym pair, but rather operates systematically by selecting the member of the pair which is linguistically simpler or "unmarked" before he acquires the "marked" term. To date, research findings concerning "markedness" have been contradictory. $2,11,13$

The notion of "markedness" is prominent in another aspect of $H$. Clark's theory concerning the sequence of acquisition' of the dimensional adjective pairs. He proposes that the pairs differ in their conditions of application according to the nature of their dimensionality. 9 The fewer dimensions an adjective presupposes, the less complex the adjective will be, and therefore the less "marked". Adjective pairs involving only one dimension will be acquired before those involving two or three dimensions. 9 Other authorities have found support for this prediction. 1,3

H. Clark $^{8}$ therefore proposes that the intrinsic properties of the 
antonym pairs could affect their sequence of acquisition. He suggests that the child first uses the terms in a nominal, non-comparative sense only. Here the appropriate dimension is indicated disregarding polarity; for example, both "long" and "short" mean "having length". The child gradually begins to distinguish between the terms and to use them comparatively. Bartlett ${ }^{2}$ has failed to find support for these predictions concerning polarity. Her data suggests that the concept of polarity is acquired before the concept of dimensionality. As soon as stimuli varied along a number of dimensions, judgements relating to one polar feature were more difficult. Little research has been carried out to investigate this particular prediction.

In conclusion, the correlation and complexity hypotheses, proposed by H. Clark $^{8}, 9$ make various predictions concerning the acquisition of dimensional adjectives. Research findings have supported or rejected these predictions to varying degrees.

Literature concerning the comprehension of dimensional adjectives in children with impaired language skills is scarce. Although Leonard, Bolders and Miller ${ }^{14}$ believe that these children tend to be delayed in terms of semantic relations, many questions remain unanswered. Does the pattern of dimensional adjective acquisition in these children match that of children with adequate language skills? Is there a difference in performance, on dimensional adjective comprehension tasks, between children with receptive and expressive language impairment? Further investigation is therefore indicated.

\section{METHOD}

This study aimed to assess various predictions of $\mathrm{H}$. Clark's theories and the SFH proposed by E. Clark, with respect to the acquisition of certain dimensional adjectives. The comprehension of these adjectives by children with delayed language skills was compared to that of children with normally developing language skills.

\section{HYPOTHESES}

1. The acquisition of dimensional adjectives, in Ss with normal language skills, follows a particular developmental sequence determined by the semantic complexity of the terms:- "long-short" to "tall-short" to "wide-narrow".

2. The unmarked member of a dimensional pair is acquired before the marked member of the pair, in Ss with normal language skills.

3. The concept of polarity is acquired before the concept of dimensionality, in Ss with normal language skills.

4. On examination of $\mathrm{H}_{1}, \mathrm{H}_{2}$ and $\mathrm{H}_{3}$ in relation to language impaired $\mathrm{Ss}$, a difference exists in the acquisition of dimensional adjectives by language impaired Ss. 
5. A difference exists between the performance of Ss with receptive and expressive language impairments with regard to the acquisition of various dimensional adjectives.

\section{SUBJECTS}

Eight children with adequate language skills and eight children with delayed language skills, ranging in age from 3,3 to 4 years, were selected. The mean age of both the $C$ and $E$ Ss was 3,6 years. Subjects were selected according to certain criteria:-

1. Within an age range of 3,3 to 4 years, children with normally developing language are reported to be able to differentiate between the members of the dimensional adjective pairs under investigation. ${ }^{13}$ Evidence that the acquisition of these adjectives continues after 4 years, ${ }^{2}$ suggests that the chosen age range will provide an opportunity to study the progression in development of the structures at this stage.

2. Both $\mathrm{C}$ and $\mathrm{E}$ groups comprised seven male $\mathrm{Ss}$ and one female $\mathrm{S}$ as this reflected the ratio of males to females attending the Speech Clinics visited. This incidence is supported in the literature..$^{15}$

3. The E Ss were diagnosed by a Speech Therapist as having delayed language skills (receptive or expressive) for their age. They had all been attending speech therapy for at least six months. The C Ss were each considered, by mothers and nursery school teachers, to have adequate language skills for their age. In addition, an objective measure was used to assess language skills. The Verbal Comprehension Scale A section of the Reynell Developmental Language Scale ${ }^{16}$ was administered to all Ss. This test acted as a screening device during the selection of $\mathrm{C}$ Ss. In the $\mathrm{E}$ group, Ss with a receptive language delay were separated from those with a purely expressive delay.

4. All Ss were required to have attended a nursery school for a minimum of six months in order to control for the influence of schooling. Each E S was paired with a C S of same sex and a similar age from the same nursery school to control further for possible differences in the schooling environments.

5. All Ss were required to come from middle to upper-middle class homes in an attempt to ensure similar environmental stimulation.

6. All Ss were judged as being of normal intelligence and to have no primary behavioural or emotional involvement.

7. Ss were required to have adequate hearing.

TEST MATERIALS

The Ss' levels of comprehension of various dimensional adjectives was the purpose of this study and a pertinent task was thus devised. Three pairs of dimensional adjectives were chosen for this study, each pair representing one of the three dimensions of length, tallness and width. The properties of these adjectives are displayed in Table I. 
TABle I: Summary of Dimensional Adjective Properties proposed by H. Clark. ${ }^{9}$

\begin{tabular}{|l|c|c|c|c|}
\hline $\begin{array}{l}\text { "Long-short" } \\
\text { "Tall-short" }\end{array}$ & $\begin{array}{c}\text { Extent or } \\
\text { position }\end{array}$ & $\begin{array}{c}\text { Number of } \\
\text { dimensions }\end{array}$ & Verticality & $\begin{array}{c}\text { Point of } \\
\text { reference }\end{array}$ \\
\hline "Wxtent & 1 & - & $\begin{array}{l}\text { ego (primary) } \\
\text { ground level } \\
\text { (primary) } \\
\text { secondary edge }\end{array}$ \\
\hline
\end{tabular}

Although the pair implying width involves only two dimensions, it will be more cognitively and semantically complex than that of tallness, involving three dimensions, since it refers to the secondary feature of a reference object. The perception of a secondary feature, rather than that of a primary feature, is necessarily more complex. These particular dimensional adjective pairs were therefore chosen because of their varying complexities. The unmarked members of the dimensional pairs are, according to $\mathrm{H}$. Clark" "long", "tall" and "wide". The marked pair members are "short", "short" and "narrow" respectively.

\section{NATURE OF THE STIMULI AND THE EQUIPMENT USED}

The stimuli consisted of object pairs which were varied systematically along certain dimensions according to the relevant dimensional adjective pair and the complexity of the task required.

1. To assess the acquisition of features of polarity, apart from the acquisition of dimensionality, only the relevant dimension was varied, that is the objects differed along only a single dimension; one pair differed in length (strings of beads), one in tallness (cardboard human figures) and one in width (cardboard strips).

2. To assess the acquisition of features of dimensionality it was necessary to use objects which varied along at least two dimensions to determine if the child was able to extract the relevant dimension from the properties of the stimulus. ${ }^{2}$ The dimensions were varied systematically so as to determine the effect of different dimensional features on the acquisition of the relevant dimension. Doubledimensional stimuli consisted of a combination of two adjective pairs. Multi-dimensional stimuli consisted of various combinations of all the adjective pairs simultaneously. Table II presents the materials used with respect to the relevant dimensions.

\section{TEST PROCEDURE}

Each $S$ was tested individually in a quiet room with limited distractions. Testing, with a few exceptions, was carried out in the nursery school as this had the advantage of familiarity of environment of the child. Each $S$ was tested during a single session lasting approximately forty minutes. Inconsistencies found when examining

Die Suid-Afrikaanse Tydskrif vir Kommunikasieafwykings, Vol. 28, 1981 
TABLE II: Description of Double- and Multi-Dimensional Stimuli

\begin{tabular}{|c|c|c|c|c|c|c|c|c|c|}
\hline & & & & & & & & & \\
\hline & Stimulus Pairs & $\begin{array}{l}\text { Task } \\
\text { No. }\end{array}$ & $\begin{array}{r}\text { LEN } \\
(+p r\end{array}$ & $\begin{array}{l}\text { GTH } \\
\text { mary) }\end{array}$ & $\begin{array}{l}\text { TALI } \\
(+p r i\end{array}$ & $\begin{array}{l}\text { NESS } \\
\text { nary) }\end{array}$ & $\begin{array}{r}\text { WI } \\
(+\sec \end{array}$ & $\begin{array}{l}\text { TH } \\
\text { ndary) }\end{array}$ & \\
\hline & & & long & short & tall & short & wide & narrow & \\
\hline 㝘 & $\begin{array}{l}\text { Cardboard flags } \\
\text { Two strips of paper }\end{array}$ & $\begin{array}{l}1 \\
2 \\
3 \\
4\end{array}$ & & & $\begin{array}{c}\text { long } \\
\text { short } \\
- \\
-\end{array}$ & $\begin{array}{c}\text { short } \\
\text { long } \\
- \\
-\end{array}$ & $\begin{array}{c}- \\
\text { long } \\
\text { short }\end{array}$ & $\begin{array}{l}- \\
\text { short } \\
\text { long }\end{array}$ & 䲞 \\
\hline 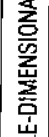 & $\begin{array}{l}\text { Cardboard dogs } \\
\text { Cardboard trees }\end{array}$ & $\begin{array}{l}1 \\
2 \\
3 \\
4\end{array}$ & $\begin{array}{c}\text { tall } \\
\text { short } \\
- \\
-\end{array}$ & $\begin{array}{c}\text { short } \\
\text { tall } \\
- \\
-\end{array}$ & & & $\begin{array}{c}- \\
\text { tall } \\
\text { short }\end{array}$ & $\begin{array}{c}- \\
\text { short } \\
\text { tall }\end{array}$ & 咅 \\
\hline 产 & $\begin{array}{l}\text { Two strips of paper } \\
\text { Cardboard houses }\end{array}$ & $\begin{array}{l}1 \\
2 \\
3 \\
4\end{array}$ & $\begin{array}{c}\text { wide } \\
\text { narrow } \\
- \\
-\end{array}$ & $\begin{array}{c}\text { narrow } \\
\text { wide } \\
- \\
-\end{array}$ & $\begin{array}{c}\text { - } \\
\text { wide } \\
\text { narrow }\end{array}$ & $\begin{array}{c}- \\
\text { narrow } \\
\text { wide }\end{array}$ & & & 흠 \\
\hline $\begin{array}{l}\tilde{t} \\
\dot{y} \\
\underline{z} \\
\underline{x}\end{array}$ & Green blocks & $\begin{array}{l}1 \\
2 \\
3 \\
4\end{array}$ & & & $\begin{array}{l}\text { long } \\
\text { long } \\
\text { short } \\
\text { short }\end{array}$ & $\begin{array}{l}\text { short } \\
\text { short } \\
\text { long } \\
\text { long }\end{array}$ & $\begin{array}{l}\text { long } \\
\text { short } \\
\text { long } \\
\text { short }\end{array}$ & $\begin{array}{l}\text { short } \\
\text { long } \\
\text { short } \\
\text { long }\end{array}$ & 尜 \\
\hline $\begin{array}{l}\text { 은 } \\
\text { 至 } \\
\text { 言 } \\
\text { 立 }\end{array}$ & Pink blocks & $\begin{array}{l}1 \\
2 \\
3 \\
4\end{array}$ & $\begin{array}{l}\text { tall } \\
\text { tall } \\
\text { short } \\
\text { short }\end{array}$ & $\begin{array}{l}\text { short } \\
\text { short } \\
\text { tall } \\
\text { tall }\end{array}$ & & $\begin{array}{c}\text { tall } \\
\text { short } \\
\text { tall } \\
\text { short }\end{array}$ & & $\begin{array}{l}\text { short } \\
\text { tall } \\
\text { short } \\
\text { tall }\end{array}$ & 胥 \\
\hline 疋 & Blue blocks & $\begin{array}{l}1 \\
2 \\
3 \\
4\end{array}$ & $\begin{array}{c}\text { wide } \\
\text { wide } \\
\text { narrow } \\
\text { narrow }\end{array}$ & $\begin{array}{l}\text { narrow } \\
\text { narrow } \\
\text { wide } \\
\text { wide }\end{array}$ & $\begin{array}{c}\text { wide } \\
\text { narrow } \\
\text { wide } \\
\text { narrow }\end{array}$ & $\begin{array}{c}\text { narrow } \\
\text { wide } \\
\text { narrow } \\
\text { wide }\end{array}$ & & & 咅 \\
\hline
\end{tabular}

D-d; for example, Task 1 for the adjective pair "long-short" involved the contrasting of two flags of the dimensions:- (1) "long-tall"

(2) "short-short".

M-d; for examplc, Task 1 for the adjective pair "long-short' involved the contrasting of two blocks of the dimensions: (1) long/tall/wide

(2) short/short/narrow.

various research results concerning the field of acquisition of dimensional adjectives could be attributed to their varying methodologies. ${ }^{2,13}$ The task type of this study was based on that used by Bartlett ${ }^{2}$ since her method of eliciting responses indicating comprehension appears to exclude variables such as cognitive complexity. A pair of objects was placed in front of the S who was asked to "Give me the - (object)", where "—" was one of the dimensional adjectives and (object) was the name of the stimulus, for example "Give me the long dog". Two pre-test tasks ensured the S's understanding of the directions. Each object pair was presented twice; once when the unmarked adjective of the pair was asked for and once when the marked adjective was required. Objects were presented to each $S$ in random order, within 
the adjective pair categories, except for the requirement that no object pair was presented twice in succession.

Scoring consisted of correct/incorrect marking to promote statistical analysis. Information to aid in a qualitative analysis was also recorded.

\section{RESULTS}

Two types of analyses were applied to the data. A quantitative analysis, the Mann-Whitney U-Test for independent samples, ${ }^{10}$ determined whether a statistically significant difference existed between the various measures obtained for the $C$ and $E$ groups. Significance at a 0,05 level for a one-tailed test was determined. A qualitative analysis in the form of descriptive evaluation of the findings obtained by both groups highlighted trends in the findings.

The results are discussed within a framework provided by the hypotheses. Overall test results are presented in Table III. The results of the statistical test are presented in Table IV.

TABLE III: Number and percentage, ${ }_{3}$ of Correct Responses obtained by $E$ and $C$ Subjects

\begin{tabular}{|c|c|c|c|c|}
\hline & \multirow{2}{*}{ 号 } & LEN & TALLNESS & WIDTH \\
\hline & & $\begin{array}{cc}\text { long } & \text { short } \\
(+) & (-)\end{array}$ & $\begin{array}{ll}\text { tall } & \text { short } \\
(+) & (-)\end{array}$ & $\begin{array}{cc}\text { wide } & \text { narrow } \\
(+) & (-)\end{array}$ \\
\hline $\begin{array}{l}\text { 岁 } \\
\text { 䒺 }\end{array}$ & $\mathbf{E}$ & $\begin{array}{c}7 / 87,5 \% \quad 6 / 75 \% \\
\underline{13 / 81 \%} \\
8 / 100 \% \quad 7 / 87,5 \% \\
\underline{15 / 94 \%}\end{array}$ & $\begin{array}{c}4 / 50 \% \quad 5 / 62,5 \% \\
\frac{9 / 56 \%}{5 / 62,5 \%} \\
7 / 87,5 \% \quad \frac{12 / 75 \%}{1}\end{array}$ & $\begin{array}{c}6 / 75 \% \quad 2 / 25 \% \\
\frac{8 / 50 \%}{5 / 62,5 \% \quad 5 / 62,5 \%} \\
10 / 62,5 \% \\
\end{array}$ \\
\hline $\begin{array}{l}\frac{1}{2} \\
\stackrel{m}{5} \\
0 \\
0 \\
\end{array}$ & $\mathrm{E}$ & $\begin{array}{c}24 / 75 \% \quad 18 / 56 \% \\
42 / 66 \% \\
27 / 84 \% \quad 24 / 75 \% \\
\underline{51 / 80 \%}\end{array}$ & $\begin{array}{c}13 / 41 \% \quad 15 / 47 \% \\
28 / 44 \% \\
27 / 84 \% \quad 20 / 62,5 \% \\
47 / 73 \% \\
\end{array}$ & $\begin{array}{c}11 / 34 \% \quad 5 / 16 \% \\
\frac{16 / 25 \%}{21 / 66 \% 15 / 47 \%} \\
36 / 56 \% \\
\end{array}$ \\
\hline 㸃 & $\begin{array}{l}E \\
C\end{array}$ & $\begin{array}{c}27 / 84 \% \quad 13 / 41 \% \\
40 / 62.5 \% \\
32 / 100 \% \quad 26 / 81 \% \\
\underline{58 / 91 \%}\end{array}$ & $\begin{array}{c}16 / 50 \% \quad 13 / 41 \% \\
\underline{29,45 \%} \\
22 / 69 \% \quad 20 / 62,5 \% \\
\underline{42 / 66 \%}\end{array}$ & $\begin{array}{c}9 / 28 \% \quad 3 / 9 \% \\
14 / 44 \% \frac{12 / 19 \%}{13 / 41 \%} \\
\underline{27 / 42 \%}\end{array}$ \\
\hline
\end{tabular}

$(+)=$ unmarked term, $(-)=$ marked term.

\section{Sequence of Acquisition of Dimensional Adjective Pairs.}

The obtained percentages indicate that there is a distinct sequence of acquisition in the comprehension of the three dimensional adjective pairs across all tasks for single-, double- and multi-dimensional stimuli; that is, length to tallness to width. $\mathrm{H}_{1}$ may therefore be accepted. The $\mathrm{E}$ group also demonstrates a similar sequence in the acquisition of the dimensional terms. This sequence is not particularly well-defined for the single-dimensional terms. 
TABLE IV: Results of the Mann-Whitney U-Test Comparing C and E Group Performance

\begin{tabular}{|c|c|c|c|c|c|}
\hline Category & \multicolumn{3}{|c|}{$\begin{array}{c}\text { Dimension } \\
\text { /Adjective Pair }\end{array}$} & $\mathrm{U}$ & Implications (E Ss) \\
\hline \multirow{3}{*}{$\begin{array}{l}\text { Sequence of } \\
\text { acquisition of } \\
\text { dimensional } \\
\text { adjective pairs }\end{array}$} & Single & \multicolumn{2}{|l|}{$\begin{array}{l}\text { length } \\
\text { tallness } \\
\text { width }\end{array}$} & $\left.\begin{array}{l}36,5 \\
40,5 \\
38\end{array}\right)$ & $\begin{array}{l}\text { Not significantly } \\
\text { different or } \\
\text { delayed. }\end{array}$ \\
\hline & Double & \multicolumn{2}{|l|}{$\begin{array}{l}\text { length } \\
\text { tallness } \\
\text { width }\end{array}$} & $\left.\begin{array}{l}46,5 \\
* 49 \\
* 55,5\end{array}\right]$ & $\begin{array}{l}\text { Not delayed. } \\
\text { Delayed in adjective } \\
\text { acquisition. }\end{array}$ \\
\hline & Multi & $\begin{array}{l}\text { length } \\
\text { tallness } \\
\text { width }\end{array}$ & & $\begin{array}{l}* 58,5 \\
41,5 \\
* 52\end{array}$ & $\begin{array}{l}\text { Delayed. } \\
\text { Not delayed. } \\
\text { Delayed. }\end{array}$ \\
\hline \multirow[t]{3}{*}{$\begin{array}{l}\text { Order of } \\
\text { acquisition of } \\
\text { adjective pair } \\
\text { members }\end{array}$} & Single & $\begin{array}{l}\text { length } \\
\text { tallness } \\
\text { width }\end{array}$ & $\begin{array}{l}+ \\
- \\
+ \\
- \\
+ \\
-\end{array}$ & {$\left[\begin{array}{l}36 \\
36 \\
44 \\
32 \\
28 \\
44\end{array}\right\}$} & $\begin{array}{l}\text { Not significantly } \\
\text { different or } \\
\text { delayed. }\end{array}$ \\
\hline & Double & $\begin{array}{l}\text { length } \\
\text { tallness } \\
\text { width }\end{array}$ & $\begin{array}{l}+ \\
- \\
+ \\
+ \\
+\end{array}$ & $\left.\begin{array}{l}34 \\
45 \\
48,5 \\
40,5 \\
48,5 \\
53,5\end{array}\right)$ & $\begin{array}{l}\text { Not significantly } \\
\text { delayed. } \\
\text { Delayed for marked term. }\end{array}$ \\
\hline & Multi & $\begin{array}{l}\text { length } \\
\text { tallness } \\
\text { width }\end{array}$ & $\begin{array}{l}+ \\
- \\
+ \\
+ \\
+ \\
-\end{array}$ & {$\left[\begin{array}{l}* 52 \\
* 54,5 \\
41 \\
40,5 \\
40 \\
* 51,5\end{array}\right]$} & $\begin{array}{l}\text { Delayed for marked and } \\
\text { unmarked term. } \\
\text { Not significantly } \\
\text { delayed. } \\
\text { Delayed for marked term. }\end{array}$ \\
\hline \multirow[t]{3}{*}{$\begin{array}{l}\text { Sequence of } \\
\text { acquisition of } \\
\text { polarity and } \\
\text { dimensionality }\end{array}$} & Length & \multicolumn{2}{|l|}{$\begin{array}{l}\text { single } \\
\text { double } \\
\text { multi }\end{array}$} & $\begin{array}{r}36,5 \\
45,6 \\
* 58,5\end{array}$ & $\begin{array}{l}\text { Not significantly } \\
\text { delayed on these tasks. } \\
\text { Delayed when task complex }\end{array}$ \\
\hline & Tallness & \multicolumn{2}{|l|}{$\begin{array}{l}\text { single } \\
\text { double } \\
\text { multi }\end{array}$} & $\begin{array}{l}40,5 \\
* 49 \\
41,5\end{array}$ & $\begin{array}{l}\text { Not delayed. } \\
\text { Delayed on double- level. } \\
\text { Not delayed. }\end{array}$ \\
\hline & Width & \multicolumn{2}{|l|}{$\begin{array}{l}\text { single } \\
\text { double } \\
\text { multi }\end{array}$} & $\begin{array}{l}38 \\
* 55,5 \\
* 52\end{array}$ & $\begin{array}{l}\text { Not delayed. } \\
\text { Delayed in the acquisi- } \\
\text { tion of dimensionality. }\end{array}$ \\
\hline
\end{tabular}

$(+)=$ unmarked term, $(-)=$ marked term

* indicates a statistically significant result with $U \geqslant 49$.

On comparing the $\mathrm{C}$ and ESs on their task performance ESs do not show any uniform significant delay across all the comprehension tasks of the adjective pairs, as expected. Significant differences were obtained on double-dimensional tasks of tallness and width, and on 
multi-dimensional tasks of length and width indicating a delay of the $\mathrm{E}$ group in these areas. $\mathbf{H}_{4}$, in relation to $\mathbf{H}_{1}$, may therefore only be partly accepted.

\section{Order of Acquisition of Adjective Pair Members}

Many of the findings relating to the CSs' performance, indicate only a slight discrepancy between the acquisition of unmarked and marked terms (in favour of the unmarked term). Only width reveals a more decisive difference between the acquisition of the pair members. However, the writer feels that $\mathrm{H}_{2}$ may be accepted for reasons considered in the discussion. Findings for the ESs generally reveal a superiority in the comprehension of the unmarked terms. The only statistically significant difference, between the C and ESs, in the acquisition of unmarked and marked terms exists on the multidimensional task involving length. The acquisition of the marked term of width for double- and multi-dimensional tasks was also significantly different. $\mathrm{H}_{4}$, in relation to $\mathrm{H}_{2}$, may only be partly accepted.

\section{Sequence of Acquisition of Polarity and Dimensionality}

Here, the Ss' performance on single-dimensional adjective tasks (representing polarity), and double- and multi-dimensional adjective tasks (both representing a different degree of dimensionality) were considered. Findings, for the CSs, involving tallness and width support $\mathrm{H}_{3}$ since task difficulty increases from single- to double- to multidimensional tasks. The ESs' performance suggests a similar progression of difficulty for all adjective pairs. The ESs do not show any general significant difference from the CSs across dimensional tasks involving length or tallness. Significant differences were found to exist on measures of width. Although, both C and ESs appear to experience increasing difficulty with increasing dimensionality, the ESs demonstrate a significant delay in the acquisition of width, especially for double- and multi-dimensional tasks. $\mathbf{H}_{4}$, in relation to $\mathbf{H}_{3}$, may therefore only be accepted for the dimensional adjective pair of width.

\section{ESs' Performance in terms of the Presence of a Receptive or Depressive Language Delay}

The E group was divided equally into Ss with receptive and purely expressive language impairment by the language pre-test. ${ }^{16}$ These two sub-groups were compared on their comprehension of the adjective pairs under all the different task conditions: On application of the statistical test, the groups do not show any significant differences with regard to the acquisition of various dimensional adjectives. $H_{5}$ is therefore rejected. 


\section{DISCUSSION}

Sequence of Acquisition of Dimensional Adjective Pairs

The results obtained by both $\mathrm{C}$ and ESs did indicate a progression in acquisition from length to tallness to width across all dimensional tasks. This finding therefore supports the trend in the literature. ${ }^{2,9}$ In trying to explain why some adjective pairs should be acquired later than others, it appears to be reasonable to assume that these pairs involve a greater semantic complexity and are thus more difficult to learn. If cognition and language are linked, as suggested in the literature, it is possible that semantic complexity would imply cognitive complexity. These more complex terms would then be acquired later on the developmental scale at a stage when the child's innate cognitive processes are more evolved. A comparison between the abilities of $\mathrm{C}$ and ESs does not produce such conclusive results. ESs appear to be performing on a similar level as CSs on tasks involving singledimensions. If double- and multi-dimensional tasks are more complex than single-dimensional tasks, ${ }^{9}$ this finding could indicate that ESs are operating at a less complex level and therefore fail to perform as adequately as CSs when more demanding tasks are introduced.. If this reasoning is correct, ESs may be assumed to be significantly delayed in dimensional adjective acquisition due to their inability to cope as efficiently as CSs, with the adjective pairs under varying task conditions. These findings would therefore support predictions made by Leonard et al. ${ }^{14}$

\section{Order of Acquisition of Adjective Pair Members}

Both $\mathrm{C}$ and ESs demonstrate superior comprehension of the unmarked member, as opposed to the marked member, of the dimensional adjective pairs. For CSs, however, there is frequently only a slight discrepancy between the acquisition of unmarked and marked terms across all the dimensional tasks. This could be explained by the relative stability of the adjective pairs in the Ss' repertoires; a decisive discrepancy would only be evident during the initial stages of adjective pair acquisition. ${ }^{8}$ It is evident that findings for unmarked and marked terms become more discrepant when the components of width are involved in the various combinations. This finding could be related to $\mathrm{H}_{1}$ suggesting that the adjective pair width is the last acquired in the sequence and is therefore still particularly unstable in the CSs' repertoires. Findings for the ESs could also be related to $\mathrm{H}_{1}$; ESs are still in the process of acquiring all the dimensional adjectives. Preference for the unmarked term would thus be more decisive at this stage of incomplete acquisition and is apparent during all dimensional tasks of varying complexities.

A comparison of the abilities of C and ESs reveals only isolated occurrences of a significant difference appearing to highlight a trend in the findings only in that they are evident in the more complex double- 
and multi-dimensional tasks. This could be related to $\mathbf{H}_{4}$, involving $\mathbf{H}_{1}$, where a significant difference between $\mathrm{E}$ and CSs was found on these tasks. Reduced stability of the pairs in the ESs repertoires, as compared to the CSs, could explain the delay in the ESs discrimination between these unmarked and marked terms. These results only partly support predictions made by Leonard et al. ${ }^{14}$

\section{Sequence of Acquisition of Polarity and Dimensionality}

CSs demonstrated the -acquisition of the concept of polarity prior to that of dimensionality for tallness and width. The absence of increasing difficulty with increasing dimensionality for length could be explained by the relative stability of this term in the CSs' repertoires (as suggested by $\mathrm{H}_{1}$ ). These findings fail to support the general trend in the literature stating that the comprehension of dimensional features is acquired before that of polarity features. ${ }^{9}$ They support contradictory research findings obtained by Bartlett. ${ }^{2}$ Results for the ESs suggest increasing difficulty with increasing dimensionality for all adjective pairs. It appears that, in this study, Bartlett's prediction ${ }^{2}$ can be extended to implicate language impaired Ss. The finding of a significant delay only in the acquisition of width, especially for double- and multi-dimensional tasks, on comparing the abilities of $\mathrm{C}$ and ESs could be explained in terms of $\mathrm{H}_{4}$, in relation to $\mathrm{H}_{1}$. Width, which is the most semantically complex of the adjective pairs studied, ${ }^{5}$ was found to be significantly delayed for the ESs, particularly on the more complex tasks. It is therefore logical that ESs should differ significantly from CSs in this area whereas the difference is not as marked for the other less complex adjective pairs. Although both groups show a trend towards the acquisition of polarity before dimensionality, ESs are significantly delayed in their acquisition of both of these features. Predictions made by Leonard et al $^{14}$ are only partly accepted since the ESs were not significantly delayed in all aspects of this semantic area.

\section{CONCLUSIONS}

The hypotheses based on predictions made by $\mathrm{H}$. Clark, 9 and SFH, ${ }^{5,6}$ that is $\mathrm{H}_{1}$ and $\mathrm{H}_{2}$, are supported by the data. The prediction could also, according to these findings, be extended to implicate Ss with language impairment.

$\mathrm{H}_{3}$, based on Bartlett's proposal, ${ }^{2}$ is accepted thus implying the rejection of the SFH prediction. The findings indicate that the proposal could also describe the performance of language impaired Ss.

$\mathrm{H}_{4}$, in relation to $\mathrm{H}_{1}, \mathrm{H}_{2}$ and $\mathrm{H}_{3}$, may be partly accepted indicating significant differences between $\mathrm{C}$ and ESs' performance in isolated areas only.

$\mathrm{H}_{5}$ is rejected implying similar performance by the ESs irrespective of the type of language impairment. 


\section{IMPLICATIONS}

Further research in this area is obviously necessary before broad conclusions may be drawn. Research could tend towards the establishment of norms for the acquisition of dimensional adjectives, the investigation of the acquisition of other dimensional adjectives, the expression of these adjectives, or the analysis of comparatives in terms of deductive reasoning. ${ }^{7}$

In devising a therapy programme it appears to be important to consider the normal sequence of development. This study highlighted certain areas:

1. Teaching should progress from less complex to more complex terms.

2. The unmarked member of the pair should be taught before the marked member, since this appears to be a less complex term.

3. The terms should be taught in terms of polarity features before further dimensionality is introduced. Tasks should be graded in terms of dimensionality; that is, single- to double- to multidimensional tasks.

Dimensional adjectives influence the child's perception of his world and could thus affect corresponding areas of language and perception.

\section{ACKNOWLEDGEMENTS}

The writer thanks:

Mrs. F. Schmaman of the Department of Speech Pathology and Audiology, University of the Witwatersrand, for her supervision.

\section{REFERENCES}

1. Anglin, J. M. (1970): The Growth of Word Meaning. M.I.T. Press, London.

2. Bartlett, E. J. (1976): Sizing things up; the acquisition of the meaning of dimensional adjectives. J. Child Lang., 3, 205-219.

3. Bierwisch, M. (1970): On classifying semantic features. In Bierwisch, M. and Heidolph, K. E. (Eds.), Progress in Linguistics. Mouton \& Co., The Hague, Paris.

4. Brown, R. (1976): A First Language - The Early Stages. (2nd Edition). Penguin Books Ltd., England.

5. Clark, E. V. (1973): What's in a word? On the child's acquisition of semantics in his first language. In Moore, T. E. (Ed.), Cognitive Development and the Acquisition of Language. Academic Press Inc., New York.

6. Clark, E. V. (1974): Some aspects of the conceptual basis for first language acquisition. In Schiefelbusch, R. L. and Lloyd, L. L. (Eds.), Language Perspectives - Acquisition, Retardation and Intervention. University Park Press; Baltimore.

7. Clark, H. H. (1969): Linguistic processes in deductive reasoning. Psych. Review, 76, 4, 387-404. 
8. Clark, H. H. (1970): The primitive nature of children's relational concepts. In Hayes, J. (Ed.), Cognition and the Development of Language. Wiley, New York.

9. Clark, H. H. (1973): Space, time, semantics and the child. In Moore, T. E. (Ed.), Cognitive Development and the Acquisition of Language. Academic Press Inc., New York.

10. Connolly, T. G. and Sluckin, W. (1971): An Introduction to Statistics for the Social Sciences. (3rd Edition). The MacMillan Press Ltd., London.

11. Donaldson, M. and Wales, R. (1970): On the acquisition of some relational terms. In Hayes, J. (Ed.), Cognition and the Development of Language. Wiley, New York.

12. Friedman, W. J. and Seely, P. B. (1967): The child's acquisition of spatial and temporal word meanings. Child Develop., 47, 4, 1103-1108.

13. Klatzky, R. L., Clark, E. V. and Macken, M. (1973): Asymmetries in the acquisition of polar adjectives: Linguistic or conceptual? J. Experimental Child Psych., 16, 32-46.

14. Leonard, L. B., Bolders, J. G. and Miller, J. A. (1976): An examination of the semantic relation reflected in the language usage of normal and language disordered children. J. Speech Hear. Res., 19, 371-392.

15. Menyuk, P. (1971): The Acquisition and Development of Language. Prentice-Hall Inc., Englewood Cliffs, New Jersey.

16. Reynell, J. (1969): Reynell Developmental Language Scale. N.F.E.R. Publishing Co. Ltd., England.

17. Townsend, D. J. (1976): Do children interpret "marked" comparative adjectives as their opposites?. J. Child Lang., 3, 385-396. 


\section{PROFESSIONAL RESOURCES . . .}

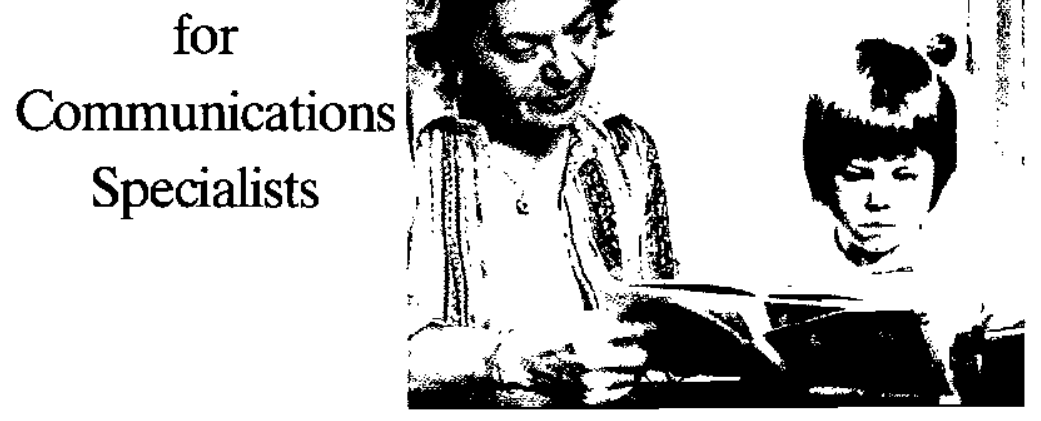

- Reading and Language Arts

- Language Development

- Assessment Materials

- Basic Skills

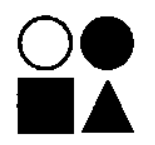

for information or free catalogues call

READ (PTY) LTD./(EDMS) BPK.

TEL: Johannesburg 39-6378 • Pretoria 44-4242 Durban 6-6669 - Cape Town 22-0947 Pietermaritzburg 5-8071 